\title{
A High-Performance Wastewater Treatment System for Orange II Degradation Using a Boron-doped Diamond Electrode and Enhanced by Zeolite-TiO ${ }_{2}$ Photocatalyst
}

\author{
Daibing Luo ${ }^{1,2}$, Daichuan $\mathrm{Ma}^{1}$, Liangzhuan $\mathrm{Wu}^{2, *}$ Jinfang $\mathrm{Zhi^{2,* }}$ \\ ${ }^{1}$ Analytical \& Testing Center, Sichuan University, No.29, Wangjiang Road, Wuhou District, \\ Chengdu, 610064, China \\ ${ }^{2}$ Key Laboratory of Photochemical Conversion and Optoelectronic Materials, Technical Institute of \\ Physics and Chemistry, Chinese Academy of Sciences, Beijing 100190, China; \\ *E-mail: Wuliangzhuan@mail.ipc.ac.cn; zhi-mail@mail.ipc.ac.cn
}

doi: $10.20964 / 2018.06 .45$

Received: 1 February 2018 / Accepted: 30 March 2018 / Published: 10 May 2018

\begin{abstract}
A wastewater treatment system has been studied which is composed of an electrochemical cell and a photocatalysis unit. A boron-doped diamond (BDD) electrode and $\mathrm{TiO}_{2}$-loaded zeolite (zeolite- $\mathrm{TiO}_{2}$ ) were used in the electro-photo process, and the joint treatment efficiency was assessed Orange II degradation. The photo-electro treatment of Orange II in aqueous solution was monitored using a combination of HPLC and UV-visible absorption spectroscopy methods. Zeolite improves the photoefficiency of titanium dioxide due to synergistic effects of the improved generation of active radicals $\left(\mathrm{S}_{2} \mathrm{O}_{8}{ }^{2-}\right.$ and $\left.\mathrm{OH}^{*}\right)$. Orange II underwent a further rapid degradation by the introduction of zeolite- $\mathrm{TiO}_{2}$ due to strong adsorption and space effects. The degradation activity to Orange II follows the decreasing order: $\mathrm{BDD}$-zeolite- $\mathrm{TiO}_{2}>\mathrm{BDD}>$ zeolite- $\mathrm{TiO}_{2}$. The degradation rate was seen to increase with $\mathrm{OH}^{*}$ radicals resulted from $\mathrm{S}_{2} \mathrm{O}_{8}{ }^{2-}$ which produced on the BDD surface and by the zeolite- $\mathrm{TiO}_{2}$ catalyst. Orange II could be almost completely degraded to $\mathrm{CO}_{2}$ and $\mathrm{H}_{2} \mathrm{O}$ after 180 min of electrolysis time by this joint treatment system.
\end{abstract}

Keywords: boron-doped diamond; zeolite- $\mathrm{TiO}_{2}$; Orange II; photo-electro degradation

\section{$\underline{\text { FULL TEXT }}$}

(C) 2018 The Authors. Published by ESG (www.electrochemsci.org). This article is an open access article distributed under the terms and conditions of the Creative Commons Attribution license (http://creativecommons.org/licenses/by/4.0/). 